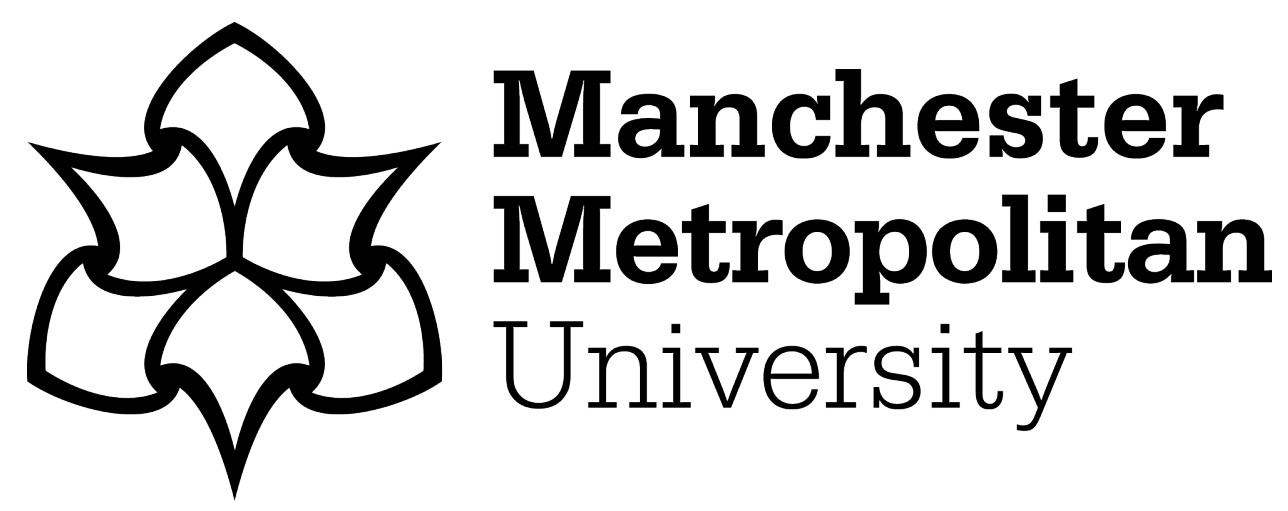

Pijetlovic, Katarina ORCID logoORCID: https://orcid.org/0000-0002-98014827 (2018) European Model of Sport: Alternative Structures. In: Research Handbook on EU Sports Law and Policy. Edward Elgar Publishing. ISBN 1784719501

Downloaded from: https://e-space.mmu.ac.uk/624312/

Version: Accepted Version

Publisher: Edward Elgar Publishing

Please cite the published version 


\title{
European Model of Sport: Alternative Structures
}

\author{
Dr. Katarina Pijetlovic
}

\section{Introduction}

European model of sport is traditionally described as monopolistic pyramid, with one federation per sport and per country. In this system, national federations organise competitions, promote, and regulate their sport at their respective national levels. They operate under the umbrella of a single European and a single global federation that sit at the apex of the pyramid. Amateur, semi-professional and professional athletes and clubs are at the bottom of the pyramid. They are members of their respective national federations and participate in various leagues according to their sporting achievements. It must, however, be emphasised that there is no uniform organisational structure of the European sports: the architecture of different sports corresponds to this broad pyramid description to various degrees.

Sports governing bodies have an extensive mandate to regulate their discipline. They pass the rules concerning the access to competitions, take care of the disciplinary and integrity matters, guarantee the uniform rules of the game, ensure the rules for safety at events are in place, promote their sport at all levels, etc. At the same time, they are also commercial actors with economic interests in the sport they regulate. In their role as organisers of competitions, they enter into a number of business deals to sell merchandise, tickets, hospitality packages, media and other commercial rights in sporting events. This intermingling of regulatory and commercial functions in a single body inevitably leads to a conflict of interests, and often causes a detriment to actual or potential competitors on the relevant market. For example, sports federations strive to maintain monopoly via the market restrictions in their statutes and other rulebooks designed to prevent the emergence of a rival, or make difficult the operation of an existing competitor, on the organisational market for sporting events. In doing so, they commit antitrust infringements under Articles 101 and 102 TFEU.

It is an interesting time to be writing about the legal issues involved in such restrictions. In 2016 the EU Commission issued a Statement of Objections in ISU, the first case after MecaMedina that addresses this question, and cross-complaints were filed between the international and European basketball federations, and private promoter of basketball competitions. A wave of recent decisions by national enforcers of EU competition law clarified the TFEU requirements applicable to regulation of organisational markets by the sporting associations. Under a general rule that expectedly emerged from this line of decisions, any clause preventing a possibility of entry and expansion in the market for organisation of sporting events will be considered restrictive of competition, unless it can be justified by reference to regulatory or commercial ancillarity. These labels imply that a reason for restriction can be legitimately attributed to either public interest objectives or to legitimate commercial goals, and that in imposing such restrictions the principle of proportionality is respected. As a matter of law, if a restriction designation cannot be avoided under ancillary restraints doctrine, in some cases a respondent might be able to rely on economic efficiency arguments. Before moving on to provide details of this legal framework and the applicable case-law, this chapter will outline policy changes towards the traditional pyramid structure in European sports, and argue that this model is not a part of 'specificity of sport' with regard to organisational aspects.

\section{EU policy on the European model of sport}


In 1998 the Commission published a consultation document that said: "[ $t$ ]here is a European model of sport with its own characteristics. [...]Sport in Europe has a unique structure. For the future development of sport in Europe these special features should be taken into account'. ${ }^{1}$ This document rejected the free market model for the future of European sport, resisting the pressures of 'Americanisation' which is seen as the ultimate evil of excessive commercialism leading to destruction of European sporting values, the only true sporting values. ${ }^{2}$ In the Opinion given by the Committee of Regions on 'The European Model of Sport', the American model is centred too much on a business and market-oriented approach to sport making a clear distinction between professional and amateur sport and giving them totally separate structures. The Committee of Regions retained its faith in, and asserted its preference for, the European socio-cultural model. It further emphasised the special characteristics of the European model and said that the inclusion of an economic factor should not be allowed to jeopardise traditional values. ${ }^{3}$ A political consensus regarding the need to preserve the structures of sport in Europe was apparent also in other policy documents, notably in the 1999 Commission Helsinki Report with a view to safeguarding the current sports structures. This Report also considered that the inclination of certain sporting operators and large clubs to leave the federations in order to reap the maximum economic benefit from the sport for themselves alone was symptomatic of several phenomena: the rise in popularity and internationalisation of sport, and the unprecedented development in the economic dimension of sport. ${ }^{4}$ The Nice Declaration notes the developments in the world of sport, but considers that federations must continue to be the key feature of a form of organisation providing a guarantee of sporting cohesion and participatory democracy, and that ties of solidarity binding the practice of sport at every level must be preserved. ${ }^{5}$ The 2007 Parliament Report on the future of professional football in Europe (Committee on Culture and Education) noted in a similar spirit that 'European sport, and football in particular, is an inalienable part of the European identity, European culture and citizenship, and the European Football Model, characterised by open sports competitions within a pyramid structure in which several hundred thousand amateur clubs and millions of volunteers and players form the base for the top professional clubs [...]' and identified the growing concentration of economic wealth and sports power as a threat to the future of professional football in Europe. It stressed 'its attachment to the European Football Model, with its symbiotic relationship between amateur and professional football' ${ }^{6}$ The Amsterdam Declaration on Sport ${ }^{7}$ similarly centred on the social significance of sport. These policy statements are based on the desire to preserve fundamental values such as the societal role of 'sport for all', self-regulation, and solidarity between professional and amateur levels, as well as the highly beneficial effects that sports have on youth, health and social inclusion policies. ${ }^{8}$

\footnotetext{
${ }^{1}$ European Commission, The European Model of Sports, Consultation Document of DG X (1999) para. 1.3.

${ }^{2}$ Halgreen, L (2004) 'European Sports Law: A Comparative Analysis of the European and American Models of Sport' Forlaget Thomson: Copenhagen, p 64.

${ }^{3}$ Opinion of the Committee of the Regions on 'The European Model of Sport' 1999/C 374/14.

${ }^{4}$ Report from the Commission to the European Council with a view to safeguarding the current sports structures and maintaining the social function of sport within the Community framework ('The Helsinki Report on Sport') $\operatorname{COM}(1999) 644$ final, section 2.

${ }^{5}$ Declaration on the specific characteristics of sport and its social function in Europe, of which account should be taken in implementing common policies 13948/00, Annex to the Presidency Conclusions, Nice ('Nice Declaration').

${ }^{6}$ See Motion for the Parliament Resolution in the European Parliament Report on the future of professional football in Europe (2006/2130(INI)), Committee on Culture and Education, final A6-0036/2007.

${ }^{7}$ Declaration on sport in Amsterdam Treaty, Declaration no. 29 ('Amsterdam Declaration').

${ }^{8}$ Halgreen, op. cit., fn. X, p. 64.
} 
The Commissioner responsible for EU competition policy addressed the question of a single federation per sport in 2001, and acknowledged that ' $[\mathrm{w}]$ hile the existence of a single federation overseeing both the regulatory and organisational aspects of a sport is common in Europe [...] other scenarios exist or can be envisaged.' 9 This signalled a move in the articulation of sports policy away from the prevalent socio-cultural approach towards a more economic-based approach, to be set out in the Commission's 2007 White Paper on Sport. ${ }^{10}$ The Commission Staff Working Paper annexed to the White Paper saw the relevance of the pyramid structure for both the organisation of competitions and sport in general as 'greatly reduced'. ${ }^{11}$ The Commission first repeated the previous policy statements on the pyramid structure and labelled certain values and traditions of European sport as worthy of support. But then it went on to recognise the diversity and complexities of European sport structures which make it unrealistic to try and define a single organisational model of sport in Europe. ${ }^{12}$ Garcia saw this as the Commission's withdrawal of an important element of the political debate, which it did partly because the pyramid model has been politicized and used in arguments by governing bodies, such as IOC, UEFA and FIFA, to further their own agenda, and avoid the legal intervention by public authorities and legitimacy challenges by other stakeholders, such as clubs and athletes. ${ }^{13}$ The White Paper further acknowledged that '[n]ew tendencies are challenging the traditional vision of a unified 'European Sport Model'. ${ }^{14}$ These challenges to the organisational structures are the increasing commercialisation and the emergence of new stakeholders outside the sports (such as aspiring private promoters) and inside the sports (such as FIFPro, ECA, and EPFL in football). This supplied another reason for the shift from policy that strongly supported vertical pyramid model to the appreciation of the necessity for a decentralised model that might be more appropriate given the prevailing empirical reality.

\section{Is European model of sport a part of Article 165(1) TFEU 'specificity of sport' concept?}

The 'specificity of sport' is the concept that refers to the inherent characteristics of sport which set it apart from other economic and social activities. ${ }^{15}$ It has never been set in absolute terms by the Court as its original creator and, as emphasised in the Commission Staff Working Document, its application is always assessed on a case-by-case basis. ${ }^{16}$ The Lisbon Treaty amendments that entered into force on 1 December 2009 provided constitutional basis to the concept of 'specificity of sport'. Article 165(1) TFEU states that '[t]he Union shall contribute to the promotion of European sporting issues, while taking account of the specific nature of sport, its structures based on voluntary activity and its social and educational function'. The study on the Lisbon Treaty and European Union Sports Policy commissioned by the European Parliament concluded that Article 165(1) TFEU will add little further protection for contested

\footnotetext{
${ }^{9}$ Mario Monti, European Commissioner for Competition 'Competition and Sport Rules of the Game' Speech/01/84. Conference on 'Governance in Sport', Brussels 26 February 2001.

${ }^{10}$ Commission White Paper on Sport, Brussels 11 July 2007 COM(2007) 391 final, (White Paper on Sport).

${ }^{11}$ Commission Staff Working Document, The EU and Sport: Background and Context, Accompanying

Document to the White Paper on Sport, COM (2007) 391 final, para. 4.1.

12 White Paper on Sport, op.cit., fn. X, para. 4.

${ }^{13}$ Garcia, B (2009) 'Sports Governance after the White Paper: The Demise of the European Model?' International Journal of Sports Policy 1(3) pp. 267-284.

${ }^{14}$ White Paper on Sport, op.cit., fn. X, para. 4.

${ }^{15}$ Mapping and Analysis of Specificity of Sport, A Final Report to the DG Education \& Culture of the European Commission, June 2016, para. 1.2. Available at http://ec.europa.eu/assets/eac/sport/library/studies/mappinganalysis-specificity-sport en.pdf

${ }^{16}$ Commission Staff Working Document, op.cit. fn. X, para. 4.1.
} 
sports rules beyond those already provided by the Court and the Commission because the two institutions have already been highly receptive to the 'specific nature of sport' concept. ${ }^{17}$

The 2011 Commission Communication on Developing European Dimension in Sport interprets the 'specificity of sport' referred to in Article 165 TFEU as the concept encompassing 'all the characteristics that make sport special, such as for instance the interdependence between competing adversaries or the pyramid structure of open competitions' ${ }^{18}$ This quote does not say anything about organisational model or governance of sport, as it is perfectly possible to have vertical structure of competition with central regulatory authority without vertical structure of organisational market. What it does imply is that promotion and relegation with a single European champion per sport are a part of 'specificity of sport' concept in Article 165 TFEU. In economic theory, it is a peculiarity of professional sport production that championships must possess a monopoly status to achieve consistent ranking and increase their value for consumers. ${ }^{19}$ So all that the Communication emphasised is the need to take this into account in the application of the EU economic provisions. Aspects of 'specificity of sport' concept thus taken into account will not necessarily prevail in the balancing act against economic aspects in a potential dispute. The quote also suggests that closed leagues would be opposed to specific nature of European sport within the meaning of Article 165(1) TFEU, and would not be able to benefit for it. However, the EU will not directly impose any particular organisational model on any sport, because each sport has its specificities and deserves to be treated accordingly. ${ }^{20}$

\section{Restrictions on alternative sports organisers: analysis under EU competition law}

The relevant market for provision of organisational services is attractive for prospective entrants because it automatically enables access to one of the connected markets: the downstream market for commercial exploitation. This primarily includes sales of broadcasting and other media rights, but also product licensing, ticketing, sponsorship, merchandising, etc. In MOTOE the Court defined the relevant market as consisting in 'first, the organisation of motorcycling events and, second, in their commercial exploitation'. ${ }^{21}$ Those two types of activities were seen as functionally complementary. Being the sole organisers enables governing bodies to have the exclusivity over commercial exploitation. The market for services of athletes and/or clubs represents the upstream market. Governing bodies regulate the labour market and player mobility, they engage in club licensing, and control other factors of production of the sporting product: the game.

There are three main ways that sports governing bodies restrict or prevent the emergence of a new competitor on the market for organisational services. The first way is to insert clauses in their statutes and other rulebooks that render the access to that market a subject to prior authorisation, but in practice make it excessively difficult to obtain such authorisation. This

\footnotetext{
${ }^{17}$ European Parliament, Directorate-General for Internal Policies, study on the Lisbon Treaty and EU Sports Policy (2010), p 10-11.

${ }^{18}$ Communication from the Commission to the European Parliament, the Council, the European Economic and Social Committee, and the Committee of the Regions 'Developing the European Dimension in Sport' $\operatorname{COM}(2011) 12$ final, 18. 1. 2011, para 4.2.

${ }^{19}$ Dietl, H., et al. (2011) Organisational Differences between U.S. Major Leagues and European Leagues: Implications for Salary Cap. International Association of Sports Economists, Working Paper Series, Paper No $11-05$, p. 3.

${ }^{20}$ Whiter Paper on Sport, op. cit. fn. x, para 4.1.

${ }^{21}$ Case C-49/07 Motosykletistiki Omospondia Ellados NPID (MOTOE) v Elliniko Dimosio [2008] ECR I-4863, para 33.
} 
has thus far been the case in many sports, including European football. Articles 49 (1) and (3) of the UEFA Statutes confer the sole jurisdiction on UEFA to organize or abolish international competitions in Europe in which Member Associations and/or their clubs participate. Any international matches, competitions or tournaments which are not organized by the UEFA, but are played on UEFA territory, shall require the prior approval of FIFA and/or UEFA and/or the relevant Member Association(s). ${ }^{22}$ This way of controlling access to market and making it subject to prior authorisation is not objectionable per se. It is after all a legitimate mandate of the governing bodies to act on behalf of entire sporting community and protect public interests in their respective disciplines. Not exercising the necessary degree of supervision and leaving regulation of sport to multiple private operators would clearly not be in the interest of sport. In internal market cases the systems subjecting the marketing of goods and services to a prior authorisation procedure are justified if they pursue a public interest objective and comply with the principle of proportionality. ${ }^{23}$ In Canal Satélite Digital the Court specified that in determining whether a system of ex ante control complies with the principle of proportionality, it is important to consider: whether a system is based on objective, non-discriminatory criteria which are known in advance so that the regulatory power is not used arbitrarily; whether a system duplicates the control already carried out; whether subsequent control system would be too late to be genuinely effective to attain the aim pursued, and; whether on account of its duration and the disproportionate cost it deters the operators concerned from pursuing their business plan. ${ }^{24}$ Similar considerations apply in competition law: transparent, objective, fair, non-discriminatory and proportionate criteria directed at pursuing public interest goals will be accepted as legitimate. ${ }^{25}$ In Metro the restrictions in a selective distribution scheme were held to fall outside of Article 101(1) TFEU where they satisfy objective qualitative criteria and are applied in non-discriminatory manner. ${ }^{26}$ This is an example of ancillary restraint doctrine based on legitimate commercial objectives. So it is not the existence of the system of prior approval that can breach the competition provisions, but the precise drafting of the criteria and the way it is applied in practice.

The second way that governing bodies restrict the emergence of a new competitor on the market for organisational services is to control factors of production needed to stage a competition, such as imposing sanctions on athletes, clubs, and leagues for taking part in the rival event. For example, in ISU case, International Skating Union (ISU) threatened their athletes with a lifetime ban if they take part in any non-sanctioned event. ${ }^{27}$ Clauses such as this successfully prevent any private promoter to enter or expand in the market for organisation of events that compete with that of a governing body. A recent study that included 19 sports disciplines outlined sanctions faced by athletes for participating in events not authorized by their international sports federation. ${ }^{28}$

\footnotetext{
${ }^{22}$ UEFA Statutes, edition 2016.

${ }^{23}$ See for e.g., Case C-432/03 Commission v Portugal [2005] ECR I-9665, and Case C-390/99 Canal Satélite Digital SL v. Adminstración General del Estado, and Distribuidora de Televisión Digital SA (DTS) [2002] ECR I-607.

${ }^{24}$ Ibid., para 43.

${ }^{25}$ See Commission Notice Guidelines on Vertical Restraints, SEC(2010) 411 final, para. 175 and the case law cited therein. It is submitted that when these principles are applied to regulatory bodies pursuing public interest objectives their market shares do not matter.

${ }^{26}$ Case 26/76 Metro (I) [1977] ECR 1875.

${ }^{27}$ See Section $x$ below for details of the case.

${ }^{28}$ Asser Institute 'Background material: sanctions faced by athletes for participating in events not authorized by their international sports federation', available at

http://www.euathletes.org/fileadmin/Sanctions_faced_by athletes_overview_international_sports_federations.p $\underline{\mathrm{df}}$
} 
The third way is to draft their contract with broadcasters and sponsors in such way as to block the competitor in the exploitation market or make that market commercially unattractive. This was the case in FIA/Formula One. ${ }^{29}$ The private promoters of grand prix had a clause in their contracts preventing circuits used for Formula One races from being used for races which could compete with Formula One, while the agreements with broadcasters contained a financial penalty of up to $50 \%$ of the price paid, if they televised anything deemed to be a competitive threat to Formula One.

The core of the methodological approach in assessing whether a regulatory rule adopted by a sports association for protection of public interest objectives infringes Articles 101 and/or 102 TFEU comprises the analytical framework provided by the Meca-Medina judgement. ${ }^{30}$ According to that judgement

$[\mathrm{n}]$ ot every agreement between undertakings or every decision of an association of undertakings which restricts the freedom of action of the parties or of one of them necessarily falls within the prohibition laid down in Article [101(1) TFEU]. For the purposes of application of that provision to a particular case, account must first of all be taken of the overall context in which the decision of the association of undertakings was taken or produces its effects and, more specifically, of its objectives. It has then to be considered whether the consequential effects restrictive of competition are inherent in the pursuit of those objectives (Wouters and Others, paragraph 97) and are proportionate to them. ${ }^{31}$

A rule that passes this test will be considered an ancillary restraint, i.e., a restriction on competition that is directly related and objectively necessary for the implementation of the main non-restrictive transaction and is proportionate to it. As such, it will fall outside of the scope of Article 101(1) TFEU. ${ }^{32}$ Regulatory ancillarity ${ }^{33}$ of this kind was first introduced by the CJEU in Wouters ${ }^{34}$ and repeated in Meca-Medina, and was so far applied only in cases of regulatory restrictions imposed by collective private bodies in the public interest. The MecaMedina analytical framework does not apply to the restrictive rules of associations adopted for the protection of their private commercial interests. However, provided that such restrictive rules are directly related and objectively necessary for the implementation of the main, nonrestrictive transaction and are proportionate to it, the rule would be considered legitimate under analytically very similar 'commercial ancillarity' doctrine under Article 101(1) TFEU. Restraints on competition that were ancillary to a legitimate commercial purpose were exemplified in $D L G$ case discussed below in Section XXX. ${ }^{35}$ The exemption would have to be sought under Article 101(3) TFEU and the efficiency defence under Article 102 TFEU.

Proportionate rules conferring monopoly on the sports federations in regards to certain matters of regulatory competence present less controversy in application of this framework. Those matters are probably best be left to the governing bodies who can legitimately insist that provisions pertaining to, for example, refereeing, disciplinary matters, independence of clubs, integrity and anti-doping must be included in the regulation of alternative competitions. The Commission acknowledged that consistency of sporting regulations and rules of the game can

\footnotetext{
${ }^{29}$ See Section $\mathrm{x}$ below for details of the case.

${ }^{30}$ Commission Staff Working Document, op.cit. fn. X, para 2.1.2.

${ }^{31}$ Case C-519/04 David Meca-Medina and Igor Majcen v. Commission [2006] ECR I-6991, para 42.

${ }^{32}$ European Commission, Guidelines on the Application of Article 81 (3) of the Treaty [2004] OJ C 101/97, paras 28-31; Métropole, para 104.

${ }^{33}$ See Wendt, I.E. (2012) 'EU Competition Law and Liberal Professions: an Uneasy Relationship?' Martinus

Nijhoff: The Netherlands; Whish R (2009) 'Competition Law' $6^{\text {th }}$ edn, Oxford UP, p 126 and; Monti G (2002)

'Article 81 and Public Policy' Common Market Law Review 39(5), pp 1087-1088.

${ }^{34}$ Wouters, para 97.

${ }^{35}$ Case C-250/92 Gøttrup-Klim e.a. Grovvareforeninger v Dansk Landbrugs Grovvareselskab AmbA (DLG) [1994] ECR I-5641. Discussed below in Section xxx.
} 
be achieved only by applicability of uniform, centrally drafted rules. ${ }^{36}$ Matters of integrity, such as anti-corruption codes, anti-doping policies, or disciplinary matters are likely to constitute inherent rules in EU sports law, and are therefore best left to the competence of governing bodies in charge of their sport, subject to the proportionality principle. They should not be entrusted to clubs and private promoters as undertakings interested in private gain as opposed to safeguarding public interest. Advocate General Kokott similarly saw the uniformity of these rules as enabling participants to compare their performances, which would not be that easy if rules varied greatly from one organiser to another. Without them, in her Opinion, the public's interest and the recognition of the sport might suffer. ${ }^{37}$ The licensing system for clubs in general was listed as an example of a sporting rule unlikely to infringe the EU competition provisions in the Commission Staff Working Document. ${ }^{38}$ Ensuring the financial stability of sport clubs/teams is seen as one of the objective justifications, as it relates to the organisation and proper conduct of competitive sport. ${ }^{39}$ According to the Commission, licensing systems generally aim to ensure that all clubs respect the same basic rules on financial management and transparency, but could also include provisions regarding discrimination, violence, protection of minors and training. In Piau, the General Court accepted that FIFA regulations on a mandatory licensing system for football agents could contribute to economic progress by protecting football players, members of a sporting profession with short playing careers. ${ }^{40} \mathrm{In}$ its draft preliminary guidelines on the Application of Competition Rules to Sport of 15 February 1999, the European Commission agreed with the International Rugby Board that control over the official match calendar by a governing body is necessary for the good of the game, ensuring solidarity and development of sport at the grassroots level, matters which individual clubs, if allowed to act in their own self-interest, are unlikely to take into account. ${ }^{41}$ Control over the official event calendar is not only necessary to ensure regulatory integrity and a proper balance between different events. It also ensures that certain revenues are generated not just for the elite at the top of the pyramid but also for the benefit of football as a whole, as the competitive playing base of the pyramid would shrink without such solidarity. ${ }^{42}$

The situation is more difficult when it comes to governing bodies attempts to maintain monopoly over other issues, such as the organisation and commercial exploitation of sporting events. Conflation of regulatory and commercial functions in one body necessarily leads to conflict of interest and as such will always be carefully scrutinised. The Commission considered rules shielding sports associations from competition as a prime examples of sporting rules that may infringe completion provision. ${ }^{43}$ Thus, when a sporting federation adopts rules that lead to foreclosure in the organisational market, or that make it excessively difficult to enter or operate in that market, it will always amount to, at the very least, prima facie restriction on competition under the Meca-Medina test (the examples of three main ways that this may occur was outlined above in this section). That test provides that when a public interest accepted as legitimate is at the heart of the reason for restriction on commercial activity, the challenged rule will be further examined for its proportionality. The rules placing restrictions on alternative organisers that are not backed up by public interest objectives, that rely on them only as a mask for private commercial goals, or that are not connected to

\footnotetext{
${ }^{36}$ Developing the European Dimension in Sport, op.cit. fn. X, para 4.2.

${ }^{37}$ Opinion of AG Kokott in C-49/07 MOTOE, para 92.

${ }^{38}$ Op.cit., fn. X, para 2.2.1.7.

${ }^{39}$ Ibid. para 2.1.5.

${ }^{40}$ Case T-193/02 Laurent Piau v. Commission [2005] ECR II-209, paras 100-106.

${ }^{41}$ Jonathan Taylor and Adam Lewis 'Governing Body Restraint on Breakaways' paper presented at 'Sport and

The Law' conference, London, 31 March 2011.

42 Ibid.

${ }^{43}$ Commission Staff Working Paper, para 2.2.2.1., op.cit. fn x.
} 
'specificity of sport', will be assessed under the standard competition law framework, and Meca-Medina will not be applicable. These rules may be exempted on the basis of commercial ancillarity under Article 101(1) TFEU, or economic efficiency exemption under Articles 101(3) and 102 TFEU.

The Commission in its Staff Working Document specifies that the legitimate objectives of sporting rules will normally relate to the 'organisation and proper conduct of competitive sport'. ${ }^{44}$ It lists a number of public interest goals that have so far been accepted as legitimate in the sports-related jurisprudence of the Court and Commission decisional practice. They include the ensuring of fair sport competitions with equal chances for all athletes, the ensuring of uncertainty of results, the protection of the athletes' health and the safety of spectators, the encouragement of training of young athletes, the ensuring of financial stability of sport clubs/teams or the ensuring of a uniform and consistent exercise of a given sport. ${ }^{45}$ The Commission also emphasised that 'specificity of sport' will be taken into consideration when assessing the existence of a legitimate objective. Accordingly, in sports where lower tiers of competition and grassroots are reliant on the mechanisms of financial solidarity, the governing bodies of such sports can legitimately require a part of the profits from the alternative events to be transferred for the benefit of lower tiers of the game. Richer clubs participating in prestigious competitions usually depend on harvesting young talents and players developed by the less well-off clubs and leagues. Keeping those lower tiers financially afloat is important both for the game and to preserve their socio-cultural contribution, and it would not be sustainable to have private promoters free-ride on their developmental efforts. Financial solidarity can also be used as a mechanisms of competitive balance, the maintenance of which was held as legitimate objective in Bosman. ${ }^{46}$ Additionally, financial solidarity is one of those public policy objectives that can be repackaged as an economic efficiency argument under Article 101(3) TFEU. When UEFA notified its joint selling arrangements to the Commission, it relied on financial solidarity as a justification for exemption under Article 101(3) TFEU. It submitted and the Commission accepted, that its financial solidarity model supports the development of European football by ensuring a fairer distribution of revenues. Commission considered on the basis of well-established case law that a solidarity model improves production and stimulates the development of the sport and emphasised that it is in favour of the financial solidarity principle. ${ }^{47}$

Whether or not particular financial contributions required from the alternative organisers will pass the competition test ultimately depends on their proportionality. This is the very core of Meca-Medina analytical framework that usually determines the outcome and requires a caseby-case approach. It is important to remember when carrying out proportionality assessment that sometimes rules that are not restrictive enough can be a cause for infringement, as much as rules that are overly restrictive. ${ }^{48}$ The cases discussed below in this chapter will highlight the approach of the courts and the competition authorities at both EU and the Member State level in various factual contexts pertaining to restrictions on alternative competitions.

\section{Competition law breaches by alternative structures}

\footnotetext{
${ }^{44}$ Commission Staff Working Paper, para 2.1.5., op.cit. fn. X.

${ }^{45}$ Ibid.

${ }^{46}$ Case C-415/93 Union Royale Belge Sociétés de Football Association and others v. Bosman and others [1995] ECR I-4921, para 106.

${ }^{47}$ COMP/37.398 — Joint Selling of Commercial Rights (UEFA Champions League) [2003] OJ L 291/25, paras 164 and 165 .

${ }^{48}$ See, for e.g., Hornsby, S 'The Harder the Cap, the Softer the Law?' Sport and the Law Journal 10(2).
} 
The issue of breakaway and alternative structures is usually approached from the point of view of restrictions on rival organisers by one of the three methods outlines above in Section xxx. But it should not be assumed that rival organisers are free from claims under Articles 101 and 102 TFEU. While tendering the media rights, drafting contracts with investors and broadcasters, designing the league structure, or running already established alternative competition, they are susceptible to committing as many competition law infringements as the governing body itself. The FIBA case against Euroleague Commercial Assets (ECA) testifies to this. ${ }^{49}$ For example, access to the alternative league for clubs and athletes should be based on objective, clearly defined, non-discriminatory and transparent criteria. It would be hard to legally defend any closed league structure if challenged by the aspiring entrant or the federations concerned. ${ }^{50}$ The league that consists of all European elite clubs will likely give a rise to a collectively dominant position held by those clubs, and a dominant position as regards the organiser of such league. ${ }^{51}$ As such, these undertakings should not allow their conduct to impede the competitive structure on the market. It should be kept in mind that every assessment of competition issues is very dependent on the facts of the case, structure of the market and characteristics of the sport concerned.

\section{EU case law}

\subsection{Case C-49/07 MOTOE [2008]}

So far, there exist only three cases that raised related issues to, and provided limited guidance for evaluating clauses in the sports governing bodies' rulebooks preventing or restricting the establishment of rival structures. MOTOE ${ }^{52}$ concerned Articles 102 and 106(1) TFEU in the context of the organisation and regulation of motorcycling in Greece. Addressed to the EU Member States, Article 106(1) TFEU applies to state measures of a regulatory nature which are directed at activities of an economic nature. It does not have an independent application because it is a reference provision which can be applied only in conjunction with other TFEU articles. The rationale behind Article 106(1) TFEU is that a Member State may be held liable for the breaches of the Treaty by undertakings when the monopoly held by an undertaking is statutory.

The dispute arose over Article 49 of the Greek Road Traffic Code that conferred exclusive power on ELPA (Automobile and Touring Club of Greece) to grant consents for the organisation of motorcycling events in Greece, necessary to get license from the competent ministry. ELPA was itself organising the same kinds of events in Greece. MOTOE (Greek Motorcycling Federation) was refused the consent from ELPA for no apparent reason and therefore failed to obtain license. According to MOTOE, this refusal by ELPA amounted to abuse of its monopolistic position.

The mere creation or reinforcement of a dominant position through the grant of special or exclusive rights within the meaning of Article 106(1) TFEU was not in itself considered incompatible with Article 102 TFEU. The key question was the discretion that a Member State left for the regulatory bodies to abuse the conferred powers. Should an undertaking be under an obligation to engage in abusive practices, the Member State is responsible for the abuses

\footnotetext{
${ }^{49}$ See Section xxx below for details.

${ }^{50}$ Parrish, R., and Miettinen, S (2008) 'Sporting Exception in European Union Law' T.M.C. Asser Press: The Hague, p 213.

${ }^{51}$ Pijetlovic, K (2015) 'EU Sports Law and Breakaway Leagues in Football' Springer/Asser, pp 303-308.

${ }^{52}$ Case C-49/07 MOTOE [2008] ECR I-4863.
} 
that take place, and conversely, if an undertaking has discretion not to abuse its special powers the Member State will not be held responsible for the committed abuses. ${ }^{53}$

The Court will consider Article 106(1), in conjunction with Article 102, breached where the dominant position creates the mere possibility and circumstances which can lead the undertaking to commit an abuse. The concept of abuse in this context is interpreted expansively to include creating 'a risk of an abuse of a dominant position'. This is more reminiscent of the approach to oligopolistic markets, or to substantive assessment of concentrations, than it is to the well-established approach to Article 102 TFEU alone under which abuse has to take place in order to find violation. On the facts of the case, ELPA was itself organizing and commercially exploiting motorcycling events, and in addition was in charge of giving consent to other undertakings to organise and commercially exploit motorcycling events. These different powers placed ELPA in apparent advantage over its competitors whereby it could restrict access to the relevant market for the other operators. ${ }^{54}$ The final word of the Court on the conflict of interests between regulatory and commercial functions created by the state was that a combination of Articles 106(1) and 102 TFEU precludes:

[...]a national rule which confers on a legal person, which organises motorcycling events and enters, in that connection, into sponsorship, advertising and insurance contracts, the power to give consent to applications for authorisation to organise such competitions, without that power being made subject to restrictions, obligations and review. ${ }^{55}$

On the facts of this case there was no such control placed upon ELPA. Miettinen concludes that MOTOE provides basis to argue that since all undertakings that are endowed with regulatory powers are merely placed in a dominant position must be subject to 'restrictions, obligations and review. ${ }^{, 56}$ Weatherill similarly suggested that giving exclusive rights which lead to conflict of interests is not a problem in itself, as long as sporting federations thus endowed have 'transparent, objectively justified, and non-discriminatory procedures and criteria for selection which are followed faithfully and openly', and the applicant promoter is afforded a right to a hearing and given reasons for decisions taken, which should be reviewable by an independent body. ${ }^{57}$ Interestingly, long before MOTOE, the competition authority in Finland (Kilpailuvirasto) cautioned the Finnish Basketball Association that it had to exercise its market position and influence over the sport responsibly, and that its decisions had to be clearly reasoned and made in a transparent and timely manner. ${ }^{58}$

\subsection{Commission investigation in FIA/Formula One case}

Another case concerning the conflict of interest between the regulatory and commercial functions of a sport association involved the Fédération Internationale d'Automobile (FIA),

\footnotetext{
${ }^{53}$ For analytical comment on MOTOE that details this point see Miettinen, S (2009) 'Policing the Boundaries between Regulation and Commercial Exploitation: Lessons from the MOTOE Case.' In: Gardiner S, Parrish R, Siekmann C R (eds), EU, Sport, Law and Policy, T.M.C. Asser Press: The Hague, pp 137-149.

${ }^{54}$ Para 51 of the C-49/07 MOTOE. In Case C-41/90 Höfner and Elser v. Macrotron [1991] ERC I-1979 it was held that the state measure within the meaning of Article 106(1) will be unlawful where by exercising exclusive rights conferred on it an undertaking cannot avoid abusing dominant position. In Case C-203/96 Dusseldorp [1998] ECR I-4075 the Court held that Article 106(1) in conjunction with Article 102 will be breached where the Member State 'adopts any law, regulation or administrative provision which enables an undertaking on which it has conferred rights to abuse its dominant position.'

${ }^{55} \mathrm{C}-49 / 07$ MOTOE, paras 51 and 52.

${ }^{56}$ Miettinen (2009), op.cit. fn. X, p 147.

${ }^{57}$ Weatherill, S (2008) 'Article 82 EC and Sporting 'Conflict of Interest: The Judgment in MOTOE' The International Sports Law Journal 3-4: special addendum, p 8.

${ }^{58}$ Decision of 5 August 1995 in Case 511/61/1994, Suomen Koripalloliitto (Finnish Basketball Association).
} 
the international association for motor sport. FIA was the organiser and promoter of motor sport championships, including Formula One. ${ }^{59}$ It issued licences to any party wishing to take part in international motor sport events authorised by FIA, including track owners, vehicle manufacturers, organisers of motor sport events and drivers. License holders were allowed to organise or enter only those events authorised by FIA. Entering or organising events not authorised by FIA would mean the loss of their license and the virtual end of any commercial activity in motor sport. This way, FIA was able to control everyone and everything needed stage a rival championship that could compete with FIA's events. The Commission found evidence that the competing GTR Organisation was forced out of the market by these rules, and its GTR series was replaced by the FIA GT Championship. Further, FIA claimed the television rights to all events incorporating the FIA name into their title, which were then transferred to International Sportsworld Communicators (ISC). It also forced the Formula One teams by the terms of tripartite Concorde Agreement to assign to it all broadcasting rights in the Formula One championship, which it then transferred to Formula One Administration Ltd (FOA), a commercial rights holder. The same agreement also prevented Formula One teams from racing in any other series comparable to Formula One for a very long period of time. The promoters' rights were taken directly by FOA which has been given the power by the FIA to determine who can and cannot be a promoter of a grand prix. The promoters' contracts prevented circuits used for Formula One races from being used for races which could compete with Formula One, while the agreements with broadcasters placed a massive financial penalty, ranging from between $33 \%$ to $50 \%$ of the price paid, if they televised anything deemed by FOA to be a competitive threat to Formula One. ${ }^{60}$

In 1999, the Commission issued a Statement of Objections. It came to the preliminary conclusion that the rules described were contrary to Articles 101(1) and 102 TFEU as they gave FIA the control to block the organisation of races which competed with the events FIA promoted or organised. The Commission also objected to certain terms of the contracts between the FOA and broadcasters because they made it possible to block the organisation of motor sport events that would compete with Formula One races. Finally, the Commission objected to FIA rules according to which FIA automatically acquired TV rights to all the motor sport events it authorises even if these were promoted by a different promoter. The core of all of the objections is the conflict between the FIA's legitimate role as the regulator of international motor sport and its interests in the commercial side of motor sport. ${ }^{61}$

In 2001 the Commission closed the case ${ }^{62}$ after reaching a settlement with FIA's president Max Mosley, and CEO of FOA, Bernie Ecclestone. The settlement provided that FIA would remove conflict of interest by limiting itself to a role of sport regulator without influence over the commercial exploitation; enable access to the market and factors of production (teams and circuit owners) to rival organisations provided they meet safety standards; waive its TV rights or transfer them to the promoters concerned; and remove the anticompetitive clauses from the

\footnotetext{
${ }^{59}$ Notice published pursuant to Article 19(3) of Council Regulation No 17 concerning Cases COMP/35.163 Notification of FIA Regulations, COMP/36.638 - Notification by FIA/FOA of agreements relating to the FIA Formula One World Championship, COMP/36.776 — GTR/FIA \& others (2001/C 169/03).

${ }^{60}$ Commission Press Release IP/99/434 'Commission opens formal proceedings into Formula One and other international motor racing series’ Brussels 30 June, 1999.

${ }^{61}$ Commission Press Release IP/01/120 'Commission welcomes progress towards resolving the long-running FIA/Formula One case’ Brussels, 26 January 2001.

${ }^{62}$ Commission Press Release IP/01/1523 'Commission closes its investigation into Formula One and other fourwheel motor sports’, Brussels, 30 October 2001.
} 
agreements between FOA and broadcasters. ${ }^{63}$ In 2003 the Commission ended the monitoring of compliance with the 2001 settlement. $^{64}$

Unlike in MOTOE, in FIA/Formula One there was no element of state involvement, as the powers which enabled it to control the relevant markets were not endowed by an act of public authority but by its own rules and web of private agreements. The safeguard against unjustified refusal of licenses in the FIA/Formula One case was the obligation to insert a new clause ensuring that legal challenge against FIA decisions would be available not only within their structure but also before national courts. Both MOTOE and FIA/Formula One cases involved sporting bodies protecting private interests, rather than acting on behalf of public interests in general. Neither of the cases involved 'specificity of sport' in any form. This made them imperfect precedents for the standard type of restrictive rules on alternative establishments.

\subsection{Case C-250/92 DLG}

The closest analogy is supplied by the $D L G$ case decided in 1994 in the context of agriculture. ${ }^{65}$ DLG was a cooperative purchasing association established in order to pursue common commercial objectives for its members, as opposed to public interest objectives relied on by sporting federations under Meca-Medina test. It held 36\% of the relevant market share, which is to be contrasted with virtual monopolies held by sports governing bodies. DLG was permitted to place a restriction on their members' participation in alternative agricultural cooperatives, on the basis that the restriction in fact benefited competition and was necessary to protect legitimate goals necessary for the functioning of the cooperative. The Court said that in a market where product prices vary according to the volume of orders, the activities of cooperative purchasing associations may, relative to the size of their membership, constitute a significant counterweight to the contractual power of large producers and bring about more effective competition in some markets. ${ }^{66} \mathrm{~A}$ dual membership in competing cooperatives would jeopardize both the proper functioning of the cooperative and its contractual power in relation to producers making each association less capable to pursue its objectives. In this sense, prohibition of dual membership does not necessarily constitute a restriction of competition and may even have beneficial effects on competition. ${ }^{67}$ On the other hand, the prohibition also have adverse effects on competition because they restrict the opportunity for members to join other types of competing cooperatives and thus discourage them from obtaining supplies elsewhere. ${ }^{68}$ The Court held that the statutes of a cooperative purchasing association, forbidding its members to participate in other forms of organised cooperation which are in direct competition with it, are not caught by the prohibition in Article 101(1) TFEU and do not amount to abuse of a dominant position under Article 102 TFEU, so long as they are restricted to what is necessary to ensure the achievement of the legitimate commercial objectives. In $D L G$, this meant the proper functioning of the cooperative and ensuring its contractual power in relation to producers. ${ }^{69}$ On the facts of the case it did not appear that prohibition on dual membership went beyond what was necessary to ensure that the said objectives are met. First, the restrictions covered only the farm supplies in respect of which there existed a direct

\footnotetext{
${ }^{63}$ Commission Staff Working Document, op. cit. fn. X, para 2.2.2.1.

${ }^{64}$ Commission Press Release IP/03/1491 'Commission ends monitoring of FIA/Formula One compliance with 2001 settlement', Brussels, 31 October 2003.

${ }^{65}$ Case C-250/92 DLG [1994] ECR I-5641.

${ }^{66}$ Ibid. para 32.

${ }^{67}$ Ibid. paras 33-34.

${ }^{68}$ Ibid. para 35

${ }^{69} \mathrm{Ibid}$. paras 35, 45 and 52.
} 
relationship between sales volume and price. ${ }^{70}$ Second, non-members of DLG, including the plaintiffs, were free to make any purchases from it on the same commercial terms and at the same prices as members, except that 'non-members' were not entitled to annual discount on the amount of the transactions carried out. ${ }^{71}$ Finally, DLG's statutes authorize its members to buy fertilizers and plant protection products without using DLG as an intermediary, provided that such transactions are carried out otherwise than through an organised consortium. ${ }^{72}$

In $D L G$, much like in the subsequent Wouters and Meca-Medina judgments, the Court made it clear that a restriction on commercial freedom is not the same as a restriction on commercial freedom that restricts competition. The aims of EU competition law and policy are centred on the preservation of free competition and do not contain guarantees on unfettered commercial conduct of the all the parties. In fact, the success of many pro-competitive agreements depends on the ability to restrict conduct of some of the parties. The judgment in $D L G$ is often referred to as a precursor to Wouters, a case that supplied the core analytical framework to MecaMedina. This means that even those restrictive rules on alternative leagues that do not have public policy objectives might be able to benefit from similar analysis in Article 101(1) TFEU provided that the restrictions are necessary for the attainment of legitimate commercial goals.

\subsection{ISU case before the European Commission}

The first time that the EU institutions had an opportunity to deal directly with the governing bodies' clauses restricting the participation in alternative sporting events was in the ISU case that is currently awaiting final decision before the EU Commission. ${ }^{73}$ ISU is recognised as a governing body and a sole regulator of the sports of figure skating and speed skating on ice by the International Olympic Committee. The facts of the case go back to December 2011 when a private promoter, Icederby International, informed ISU that it intended to organise an alternative international speed skating event with innovative competition format that combined short and long track skating. The ISU reacted by revising its Code of Ethics in January 2012 that included Article 4(h), a clause forbidding participation "in all forms of betting or support betting or gambling related to any event/activity under the jurisdiction of the ISU." As per ISU Communication No. 1717, the Code of Ethics, including its Article 4(h), applied to the widest range of individuals. In addition to the customary list of covered persons such as ISU officials, skaters, coaches, doctors, employees, consultants, members and their members, also volunteers at ISU events and ISU-sanctioned Member events, and all other persons who engage in any activity in relation to the ISU that is prohibited by the Code of Ethics, were covered. ${ }^{74}$ On the basis of this article ISU refused to sanction Icederby event that was to take place in October 2014 in Dubai, even though it is a jurisdiction in which betting activities were strictly prohibited. $^{75}$

Dubai race had a dedicated sum of EUR 1.4 million in prize money and it would have paid a minimum of $\$ 37.650$ and a maximum of $\$ 130.000$ to any skater merely taking part in it. In

\footnotetext{
${ }^{70}$ Ibid. para 37.

${ }^{71}$ Ibid. para 38 .

${ }^{72}$ Ibid. para 39.

${ }^{73}$ Relevant case documents available at http://ec.europa.eu/competition/elojade/isef/case_details.cfm?proc_code $=1$ 40208

${ }^{74}$ See ISU Communications No. 1717 and No. 1853 available at http://www.isuresults.com/seminars/1717\&1784\&1853_CodeOfEthics.pdf

${ }^{75}$ Van Rompuy, B 'Dutch Speed Skating Duo Files Antirust Complaint Against the International Skating Union' 19 November 2014, LawinSport.com. Available at http://www.lawinsport.com/articles/item/dutchspeed-skating-duo-files-eu-antitrust-complaint-against-the-international-skatingunion?highlight=WyJpbnRlcm5hdGlvbmFsIHNrYXRpbmcgdW5pb24iXQ
} 
comparison, a long-track speed skater could earn as much as $\$ 109.000$, and a short-track skater $\$ 31.900$ in a season from ISU competitions. ${ }^{76}$ However, ice speed skaters were subject to two rules that made the prize money at Dubai event (and any other non-sanctioned competition) unattainable: Rule 102 (2) (ii) of the ISU General Regulations that made any person skating or officiating in a non-sanctioned event ineligible to participate in events organised by ISU, and Rule 102 (7) that provided for a possibility of a lifetime ban from all ISU competitions, including Winter Olympics and the World and European Championships (Rule 102(3)). ISU reiterated in its Communication No. 1853 that these eligibility rules will be enforced against any skaters or officials that take part in Dubai event.

Under the threat of a lifetime ban no skater would agree to participate in any of the nonsanctioned events. As a consequence of this, an alternative organiser, such as Icederby International, would be unsuccessful in its attempts to enter or expand in the market for organisation of ice speed-skating events. Top athletes represent the main factor for staging commercially viable competition and the ISU eligibility rules made it virtually impossible to acquire them.

The two Dutch ice speed skaters, Mark Tuitert and Niels Kerstholt, saw these rules as a restriction on their professional opportunities and filed a competition complaint with the EU Commission in June 2014. They alleged that ISU eligibility rules are in breach of Articles 101 and 102 TFEU because a lifelong ban for participation in alternative competition is not inherent and proportionate to the pursuit of any legitimate objective, contrary to the requirements of Meca-Medina formula. Additional issue from the point of view of skaters that directly and manifestly affected their interests were barriers to entry and expansion on the market for the organisation of international speed-skating events. ${ }^{77}$

On the basis of this complaint the EU Commission opened up formal proceedings against ISU on 5 th October 2015 to test the disputed clauses against the EU competition law parameters. ${ }^{78}$ As a response to this legal challenge the ISU amended its eligibility rules at its Congress in June 2016. ${ }^{79}$ The new Rule 102 (2) of ISU Constitution and General Regulations $2016^{80}$ provides that ' $[\mathrm{a}]$ person becomes ineligible to participate in ISU activities and competitions by skating or officiating in an International Competition not sanctioned by the ISU'. Ineligibility is imposed by the ISU Council according Rule 102 (7) (d) that provides for the sliding scale of sanctions ranging from warning to ineligibility for a lifetime. Specifically, it provides that 'ISU Council shall i) issue a warning in case of minor, first time violations; ii) impose an ineligibility period for up to five years in case of medium heavy violations and in case of repeated minor violations; iii) impose an ineligibility period for up to ten years in case of serious violations; iv) impose an ineligibility period up to life time in case of very serious violations, especially intentional violations which endanger the integrity and jurisdiction of the ISU.' The applicable sanction shall be determined in accordance with the principle of proportionality, meaning that each case will be considered on its own merits. In particular 'the

\footnotetext{
${ }^{76}$ Danielle Rossingh 'Skater's Lawsuit May End Sports Bodies' Grip on Competition’ Bloomberg, 2 December 2014. Available at http://www.bloomberg.com/news/articles/2014-12-02/skater-s-lawsuit-may-end-sportsbodies-grip-on-competion

${ }_{77}$ Van Rompuy, B. 'European Commission's ISU Antitrust Investigation Explained', The Asser International Sports Law Blog, 5 October 2015. Available at http://www.asser.nl/SportsLaw/Blog/post/the-europeancommission-s-isu-antitrust-investigation-explained-by-ben-van-rompuy\# ftnref7

${ }^{78}$ European Commission Press Release 'Antitrust: Commission opens formal investigation into International Skating Union's eligibility rules’ Brussels 5 October 2015. Available at http://europa.eu/rapid/press-release_IP15-5771 en.htm

${ }^{79}$ ISU Communication No. 2004, Agenda of the $56^{\text {th }}$ Ordinary Congress, Dubrovnik, June 2016. Available at http://static.isu.org/media/1006/2004-congress-2016-agenda.pdf

${ }^{80}$ Available at http://static.isu.org/media/1017/constitution-and-general-regulations-2016.pdf
} 
degree of fault of the offender, his previous record and the seriousness of the violation with regard to the objectives of the ISU [...], the integrity of the ISU's sports and other legitimate interests of the ISU' play a role in determining the sanctions. ${ }^{81}$ When taken together with the nuanced set of sanctions, it appears that the proportionality is applied only when the offence has already been classified as minor, medium, serious, or very serious and prescribed one of the applicable range of sanctions.

The apparent objections to the revised rules that can be raised is that there are no indications of what constitutes minor, medium and serious offences. Only the category of 'very serious offence' was broadly defined in Rule 102(7)(d)(iv) that refers to 'intentional violations which endanger the integrity and jurisdiction of the ISU.' This can be interpreted to indicate that a very long ban or a lifetime ban will be imposed in cases of participation in non-sanctioned events, as they are the very activities that directly compromise the integrity and jurisdiction of the ISU. As such, the amendments to the ISU eligibility rules appear largely cosmetic and do not deal away with the issue of disproportionate sanctions for the skaters taking part in unauthorised events. This is surprising given that the reason for which they were introduced was to address the concerns raised by the EU Commission when it opened formal proceedings in the case.

The Commission implicitly recognised that the amendments to the eligibility rules are insufficient to address the competition concerns when it issued a Statement of Objections on 27 September $2016 .{ }^{82}$ This is a formal step in antitrust investigation that sets out the position of the Commission and gives the respondent an opportunity to be heard before the adoption of a binding decision. The Commissioner in charge of the EU competition policy, Margrethe Vestager, recognised that international sports governing bodies are responsible for ensuring high standard of conduct, the health and safety of athletes and the integrity of competitions. She said that the competition concerns in the case are related to the penalties imposed on skaters through the ISU eligibility rules because in Commission's opinion they are not being aimed at preserving high standards in sport but rather serve to maintain the ISU's control over speed skating. Therefore, in its preliminary view the Commission considered that the penalties restrict both the commercial freedom of athletes and the entry to the market for the new organisers of international speed skating events. It also indicated that the restrictive clauses will be tested under the Meca-Medina framework. $^{83}$

In its response to the Statement of Objections, the ISU emphasised that independent organizers are in fact able to stage international tournaments on the ISU international calendar. In support of this claim, they cited recently authorized event in the Netherlands co-organized by Icederby International, the private entity which initiated the competition investigation via the two Dutch complainants. According to ISU, this furnished a proof rendering unfounded the Commission's claim that alternative organizers are foreclosed from the market. ${ }^{84}$

\footnotetext{
${ }^{81}$ Rule 102(3) has remained unchanged and provides that only eligible persons are permitted to take part in ISU Events, including the Olympic Winter Games and other International Competitions. Rule 103 (2) provides for reinstatement of ineligible persons upon their application once they have served half of the period of ineligibility determined, or 15 years in case of ineligibility for life-time.

${ }^{82}$ European Commission Press Release 'Antitrust: Commission sends Statement of Objections to International Skating Union on its eligibility rules’ Brussels 27 September 2016. Available at http://europa.eu/rapid/pressrelease IP-16-3201 en.htm

${ }^{83}$ Ibid

${ }^{84}$ ISU Press Release 'ISU believes that the European Commission's antitrust allegations are unfounded' 27

September 2016, Lausanne.
} 
Indeed, if ISU could prove that the entry to the organisational market is practically possible and that any refusal to sanction rival entities is only for ethical and integrity purposes, and/or to ensure that health and safety of the skaters are adequately safeguarded, they would be one step closer to successfully defending their rules. It will be the proportionality of the chosen methods to attain the legitimate objectives that will play an ultimate role in assessing the validity of eligibility rules under the TFEU competition provisions. Having said that, a lifetime ban for participating in unsanctioned event will extremely unlikely be considered proportionate and so will any other sanction or rule that can effectively put an end to athletes' careers.

The decision in this case is widely projected to alter the classic landscape of the European model of sport. It will supply an important precedent that will sooner or later affect the structure of organisational markets in all other sports in Europe, so the influence of the decision extends far beyond skating. In the near future football could see an emergence of alternative European cross-border league properly sanctioned by both the UEFA and the relevant national associations.

\subsection{Euroleague Basketball v. FIBA and FIBA Europe and FIBA v Euroleague Commercial Assets}

These two cases involving cross-complaints are discussed below in Section xxx in the context of national proceedings before Munich Regional Court.

\section{Alternative leagues in NCAs' and MS national courts' decisions}

The Commission's position in the ISU Statement of Objections comes as no surprise given the outcomes in the series of cases that took place before the Member States' national courts and national competition authorities in the past few years. The cases discussed in this section involve similar restrictions on competition as presented in $I S U$ case, and they replay in various form the underlying issues of conflation of regulatory and commercial functions in a single governing body. All of the national enforcers took the same line of approach in assessing the legality of the restrictive rules in cases decided after Meca-Medina judgement, providing inter alia an indication of effectiveness of mechanisms for preserving uniformity in the decentralised system of EU competition law enforcement.

\subsection{Sweden: $S B F$ v. KKV and IBFF cases}

In 2012 and 2014, the Swedish enforcers had an opportunity to rule on two sports cases on alternative events under EU competition law. In $S B F$ v. $K K V,{ }^{85}$ Swedish Automobile Sports Federation (SBF, Svenska Bilsportförbundet) responsible for organising automotive sport in Sweden challenged the decision of the Swedish Competition Authority (KKV, Konkurrensverket $)^{86}$ according to which SBF Common Rules forbidding its members from participating as drivers and event staff in races not sanctioned by the SBF are contrary to EU competition law. In its decision KKV found that the clauses are obviously aimed at preserving SBF monopoly, while being harmful to drivers and other interested parties, restricting

\footnotetext{
${ }^{85}$ Swedish Market Court ruling 2012:16 in Case A 5/11, Svenska Bilsportförbundet v Konkurrensverket (SBF v. $K K V) 20$ December 2012. Available at http://www.marknadsdomstolen.se/Filer/Avg\%C3\%B6randen/Dom2012-16.pdf

${ }^{86}$ Swedish Competition Authority (Konkurrensverket), Swedish Automobile Sports Federation, Decision dnr. 709/2009 of 13 May 2011. Available at http://www.konkurrensverket.se/globalassets/aktuellt/nyheter/beslutsvenska-bilsportsforbundet.pdf
} 
competition, and inhibiting the development of the automotive sport. ${ }^{87}$ Swedish Market Court (Marknadsdomstolen) confirmed the decision of KKV, and decided on the case without making a preliminary reference to the Court of Justice of the EU. ${ }^{88}$ It mirrored the approach by the $\mathrm{KKV}$ and accepted as legitimate the socio-cultural and educational objectives of sport, as well as the need to ensure safe competition, but considered the restrictions as disproportionate means of attaining those objectives. ${ }^{89}$ In particular, the SBF failed to convince the Market Court that less restrictive means were not available and that the objectives can only be safeguarded by the challenges measures which constituted an absolute ban on competition. After the court pronounced its judgement, SBF was required to amend its Common Rules and remove the clauses preventing their members to take part in unsanctioned automotive events.

Commenting on the case Lindholm correctly noted that the Market Court was not willing to rule on the organisational model of sport as such. ${ }^{90}$ This approach is consistent with the EU policy discussed above in Section xxx that emphasises the autonomy of sport to organise itself and refuses to be prescriptive as regards any structural model of sport.

It took only a couple of years before another private promoter relied on $S B F v . K K V$ precedent before Swedish Competition Authority. In 2014, BMR Sport Nutrition AB submitted a complaint under Article 101 TFEU against the Swedish Bodybuilding and Fitness Federation (SKKF), the only national member of International Bodybuilding Federation (IFBB). ${ }^{91}$ More specifically, the complaint targeted the so-called 'loyalty clause' in SKFF by-laws that provided for fines and suspensions for the members (athletes, coaches, officials and judges) who participate in contests that are not sanctioned by the SKFF or IFBB. Swedish Competition Authority closed the investigation into this case after SKFF committed to amending the 'loyalty clause' and removing the threat of fining or sanctioning their members for participation in unsanctioned events. ${ }^{92}$ It can safely be assumed that had the decision been reached, it would have mirrored the outcome in the $S B F v . K K V$ case. $^{93}$

\subsection{Ireland: Show Jumping Ireland case}

In May 2012, Irish Competition and Consumer Protection Commission closed their investigation into Article $299 \mathrm{~N}$ of the Show Jumping Ireland (SJI) Rulebook that prevented their members from competing at unaffiliated show jumping events where the prize fund

\footnotetext{
${ }^{87}$ Ibid. para. 69.

${ }^{88}$ See paras 15 and 107 of Swedish Market Court ruling in $S B F v . K K V$ in which the Market Court refused the request by $\mathrm{SBF}$ to make preliminary reference to CJEU.

89 Ibid. paras 144-146.

${ }^{90}$ Lindholm, J. (2013) 'The Impact of SBF v KKV on Sport: Swedish Fender-Bender or European Pileup?' European Competition Law Review 34:7, p 370.

${ }^{91}$ In Swedish Competition Authority (Konkurrensverket), Bodybuilding and Fitness Competitions, Decision dnr. 590/2013 of 28 May 2014. Available at http://www.konkurrensverket.se/globalassets/aktuellt/nyheter/lasbeslutet-dnr-5902013-42374kb.pdf

92 Konkurrensverket (Swedish Competition Authority) news item 'Svenska Kroppskulturförbundet ändrar tillämpning av lojalitetsregel' (translaton: Swedish Bodybuilding Association changes its application of loyalty clause) 2 June 2014, available at http://www.konkurrensverket.se/nyheter/svenska-kroppskulturforbundet-andrar-tillampning-av-lojalitetsregel. See also Swedish Competition Authority Annual Report 2014 available at http://www.konkurrensverket.se/globalassets/english/publications-and-decisions/annual-report-2014.pdf ${ }^{93}$ For more on the case see Editorial (2014) 'Swedish Bodybuilders' Competition Law Insight 13: 6, available at http://www.competitionlawinsight.com/region/europe/swedish-bodybuilders-

100584.htm?origin=internalSearch, and Van Rompuy, B. 'Sport and EU Competition Law: Uncharted Territories - (I) The Swedish Bodybuilding Case’ The Asser International Law Blog, 12 September 2014. Available at http://www.asser.nl/SportsLaw/Blog/post/sport-and-eu-competition-law-uncharted-territories-i-theswedish-bodybuilding-case-by-ben-van-rompuy\# ftnref7
} 
exceeded $€ 50 / £ 50 .{ }^{94}$ Any breach of this rule entailed penalties for members. ICCPC considered the rule likely breached Irish and EU competition law because it not only prevented SJI members from participating in unaffiliated events but it simultaneously prevented third parties from organising and hold such unaffiliated events. The SJI committed to amend the rule to address the competition concerns. Members of SJI who enter into unaffiliated show can now be penalized only if the show (i) has not signed up to the specified Health and Safety Standards; and, (ii) has not provided the SJI with evidence of adequate insurance. ${ }^{95}$

Equivalent competition law decisions against restrictive clauses of national sports governing

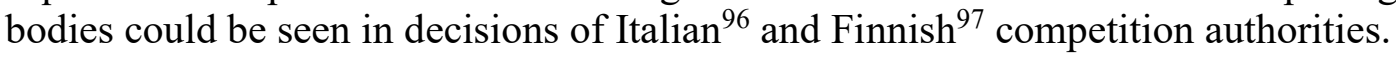

\subsection{Belgium: Global Champions League case}

In July 2015 Global Champions League case, ${ }^{98}$ Belgian Competition Authority (BCA) examined a clause in the International Equestrian Federation (FEI, Federation Equestre Internationale) General Regulations according to which FEI had exclusive rights to accredit international equestrian competitions. To receive FEI accreditation organisers were required to wave intellectual property rights even when their events did not bear the FEI name, and to comply with all FEI rules, regulations and requirements even when their contests and series did not count towards the Official FEI classification ${ }^{99}$. The 'exclusivity clause' further included a six month suspension from FEI accredited events for athletes, horses, and officials, who participated in events and/or competitions not accredited by the FEI. ${ }^{100}$ The governing body claimed that the exclusivity clause was adopted in order to protect the welfare of horses and integrity of competitions. ${ }^{101}$

When Global Champions League (GCL) applied for authorisation of a new league alongside its existing competitions, FEI declined to approve it mostly on the basis that its own Nations Cup series is sufficient to meet the demands of the sport and its participants. This reason for blocking the new GCL league is apparent from the transcripts of long negotiations that lasted for more than a year. It was clear that without FEI authorisation, the Global Champions League that was scheduled for April 2016, would not be organized and the project would have to be abandoned. GCL therefore applied to BCA for interim measures to suspend the application of the exclusivity clause. This request was held admissible and well-founded by BCA that ordered the FEI to suspend Articles 113(4)-(6) of the General Regulations with respect to the participation of athletes and horses in the Global Champions League until the final decision in

\footnotetext{
${ }^{94}$ Consumer and Competition Protection Commission news item: 'Show Jumping Ireland amend allegedly restrictive rule' available at http://ccpc.ie/show-jumping-ireland-amend-allegedly-restrictive-rule

${ }^{95}$ Compecon - Competition \& Regulatory e-zine No.9 - July 2012, pp 9-10. Available at http://www.compecon.ie/attachments/File/EZ9.pdf

${ }^{96}$ See Italian Competition Authority (Autorità Garante della Concorrenza e del Mercato) decisions in Case A378 Italian Equestrian Sports Federation, decision no. 18285 of 28 July 2008, Bollettino no. 19/2008, available at http://www.agcm.it/component/joomdoc/bollettini/19-081.pdf/download.html, and Case A396 Gargono Racing, decision no. 19946 of 11 June 2009, Bollettino no. 23/2009, available at

http://www.agcm.it/concorrenza/concorrenzadelibere/open/41256297003874BD/5764581408C13D8EC12575E60039872C.html

${ }^{97}$ The Finnish Competition Authority (Kilpailuvirasto) decision of 18 December 2002 in Case 625/61/2002, AKK - Motorsport ry, and decision of 5 August 1995 in Case 511/61/1994, Suomen Koripalloliitto (Finnish Basketball Association).

${ }_{98}$ Autorité belge de la Concurrence (Belgian Competition Authority) [2015] Décision no. ABC-2015-V/M-23 of 27 July 2015. Available at http://www.belgiancompetition.be/sites/default/files/content/download/files/2015vm23-abc-pub.pdf 99 Ibid. para 75.

${ }^{100}$ Articles $113(4)-(6)$ and $156(9)$ of the FEI General Regulations.

${ }^{101}$ Para 58 of the decision, op. cit. fn. X.
} 
the case. Also, the FEI was to indicate unambiguously in its news section that "no athlete or horse may be suspended or sanctioned as a result of participating in a competition organized under the Global Champions League". ${ }^{102}$ On 28 April 2016, the Brussels Court of Appeal refused the FEI request for annulment of the BCA interim measure. Instead, it confirmed its validity and also upheld BCA's prima facie assessment of infringement of Belgian and EU competition laws. ${ }^{103}$

While deciding on the temporary measure BAC doubted the real motivation behind the exclusivity clause and noted that the approval process lacked transparency and clarity which should have been the case given the conflict of interest between FEI regulatory and commercial functions, and that it was not based on the sporting aspect (because GCL already complied with all of them), not applied without any discrimination and not proportionate to the sporting objectives; pointed out that strict deadlines should also be implemented; noted that even if contest or series complied with all the rules and regulations of the FEI (as the Global Champions League did) the FEI could have refused to give its consent for arbitrary and commercial reasons in its sole discretion; and recognised that in 2012 and 2013 when the contested clause was introduced the FEI revenues immediately doubled. Consequently, BAC concluded that the FEI exclusivity clause prevents an independent organizer or promoter from accessing the 'raw materials' of equestrian sports (i.e., athletes, horses and officials) as no internationally competing athlete will participate in a non-accredited competition insofar as such participation prevents him/her from participating in all national and international competitions accredited by the FEI for six months. On the basis of these factors BAC concluded that the FEI approval process, applied in the context of the FEI exclusivity clause, allows the FEI to abuse its position as a sports regulator in order to promote its own commercial interests at the expense of alternative organizers and independent promoters, such as the Global Champions League. ${ }^{104}$

\subsection{Germany: Euroleague Basketball and NRWTV Triathlon cases}

Interim measures were also granted in June 2016 by the Munich Regional Court in Euroleague Basketball vs FIBA and FIBA Europe. ${ }^{105}$ The background of the dispute is interesting and procedurally unique. In February 2016 Euroleague Basketball filed a complaint on the basis of Article 102 TFEU before the EU Commission against FIBA and FIBA Europe for putting pressure on clubs, players and referees to force them to abandon the Euroleague and the Eurocup organised by Euroleague Commercial Assets (ECA) and only participate in FIBA competitions. National federations that took no steps to discipline their clubs and domestic leagues that participate in ECA competitions would lose their national team rights to participate in 2016 Rio Olympic Games and EuroBasket 2017 organised by the Respondents. ${ }^{106}$ Two month later FIBA launched an equivalent counter-complaint before the EU Commission against ECA for breaches of Article 102 TFEU, referring to the legal action against itself and

\footnotetext{
${ }^{102}$ Operating part of the decision, page 159.

${ }^{103}$ Brussels Court of Appeal, Case 2015/MR/1, Fédération Equestre Internationale/Autorité Belge de la Concurrence, 28 April 2016.

${ }^{104}$ Paras 61-80. For more on the case see Haffner, A. and Mistry, K. 'The Law on Banning Athletes from Competing in Rival Sports Leagues' 5 October 2016, Lawinsport.com available at

http://www.lawinsport.com/blog/snr-denton-blog/item/the-law-on-banning-athletes-from-competing-in-rivalsports-leagues?highlight=WyJpbnRlcm5hdGlvbmFsIHNrYXRpbmcgdW5pb24iXQ==\#references

${ }^{105}$ Munich Regional Court I, Case no.: 1 HK 0 8126/16.

${ }^{106}$ Euroleague Basketball news item: 'Euroleague Basketball presents a complaint before the European Commission against FIBA and FIBA Europe' 22 February 2016 by Euroleague.net. http://www.euroleaguebasketball.net/euroleague-basketball/news/i/6p8c54yjk66qsitp/euroleague-basketballpresents-a-complaint-before-the-european-commission-against-fiba-and-fiba-europe
} 
FIBA Europe as a smokescreen intended to mask ECA's own anti-competitive behaviour. Specifically, FIBA's complaint related to abusive tying by ECA that imposed undue pressure on leagues and clubs and threatened them with exclusion from Euroleague unless they commit to Eurocup, like in the case of Adriatic League; the fact that all Euroleague and Eurocup decisions in sporting and commercial matters are controlled by six clubs; destroying any commercial and sporting value of domestic leagues and undermining the competitive balance in European basketball by arbitrarily cherry-picking clubs for Euroleague and Eurocup, and; abusively discriminating against financially weaker clubs, thereby placing them at a further competitive disadvantage. According to FIBA, 'ECA wished to reap the benefits of the basketball ecosystem developed by national federations (players, coaches, referees, thousands of other clubs) without contributing to the foundations of the sport's pyramid and holding the national teams hostage to serve the interests of six commercially powerful clubs. ${ }^{207}$

In May 2016, a group of Euroleague and Eurocup clubs, domestic leagues and Euroleague Basketball petitioned Munich Regional Court for interim relief in an attempt to avoid irreversible damage to national teams before the EU Commission can rule on the complaint by Euroleague Basketball. ${ }^{108}$ A temporary measure was granted on 2 June 2016. The judge in the case prohibited FIBA Europe and FIBA from sanctioning or threatening to sanction, directly or indirectly, the Applicants, the basketball clubs, National Basketball Federations, or national or supra-national basketball leagues in the geographic area of FIBA Europe because of their decision or intention to co-operate with ECA and its subsidiaries. ${ }^{109}$

The EU Commission now has an option to open up formal investigation into this dispute(s), or to reject the complaint(s) on the basis of there being no sufficient EU interest. ${ }^{110}$ As far as predicting the outcome of potential investigation, both complaints have merits and if they can prove their allegations both FIBA and ECA would gain some and lose some. ECA would be forced to revamp the rules on access to their competitions (to become open, transparent and non-discriminatory), and release the clubs from obligation to play in both Euroleague and Eurocup. At the same time, FIBA would be required to remove the threat of sanctions against any of the parties taking part in ECA organised competitions. However, provided that FIBA can prove that the way the ECA competitions are organised jeopardises domestic leagues, and that the chosen sanctions are the least restrictive method capable of protecting domestic leagues, it is not inconceivable that it might prevail in both cases. Once that ECA removes its own alleged infringements, FIBA could no longer sanction any league, club or athlete cooperating with ECA on any level.

The EU law approach towards clauses restricting the establishment or operation of rival competitions is clear. On the other hand, clarification of the acceptable way to organise an alternative sporting structure would be most welcome. The EU Commission will hopefully join the two cases and open the full investigation leading to a formal decision. ${ }^{111}$

\footnotetext{
${ }^{107}$ FIBA Press Release: 'FIBA files complaint against Euroleague' 4 April 2016, available at http://www.fiba.com/news/fiba-files-complaint-against-euroleague

${ }^{108}$ Euroleague Basketball news item 'Munich Regional Court Rules against FIBA and FIBA Europe' 3 June 2016, available at http://www.euroleaguebasketball.net/euroleaguebasketball/news/i/6xfdyb9eg4ex5ioa/munich-regional-court-rules-against-fiba-and-fiba-europe-sanctions ${ }^{109}$ Munich Regional Court (Landgericht München I), AZ:: 1 HK O 8126/16, Europleague and others v FIBA Europe and FIBA, available at http://www.euroleague.net/rs/6xk9t4qutjtn5uf4/84bd1f8d-134d-42a0-a8eecd688d29aaa2/f03/filename/munich-court-decision-german.PDF

${ }^{110}$ Commission Notice on the handling of complaints by the Commission under Articles 81 and 82 of the EC Treaty (Text with EEA relevance), Official Journal C 101, 27.04.2004, p. 65-77.

${ }^{111}$ For more on the case see Montejo, M. 'FIBA/Euroleague: Basketball's EU Competition Law Champions League- first leg in the Landgericht München’ Asser International Sports Law Blog, 15 June 2016. Available at http://www.asser.nl/SportsLaw/Blog/post/fiba-euroleague-basketball-s-eu-competition-law-champions-leaguefirst-leg-in-the-landgericht-munchen-by-marine-montejo
} 
A less complicated scenario was presented in another German case. ${ }^{112}$ In April 2013, Higher Regional Court of Dusseldorf considered legal the fees that North Rhine-Westphalia Federation (NRWTV) was charging to private organisers of triathlon competitions in exchange for benefits, such as providing advertising space in their newsletter and website. The fact that the federation itself was active on the organisational market and had a conflict of interests in regulating and commercially exploiting the sport, and that there existed an actual restriction on competition, did not affect the outcome of the case. The fees charged in the case were not disproportionate to the actual benefits received. ${ }^{113}$ Therefore, when private entity did not pay proportionate fees, the refusal by the NRWTV to authorise their event did not infringe EU and German competition laws on the abuse of dominant position.

\section{Conclusion}

A recent wave of cases discussed in this chapter illustrate the kind of assessment of restrictions on alternative organisers that will be carried out by the enforcers of EU competition law at both European and national level. Even though EU law refuses to be prescriptive as regards a structural model for European sports, it would be wrong to think that it cannot and will not force changes in those models indirectly via other routes. Cases such as $S B F v . K K V$ show that inconsistency with the competition law of certain governing bodies' rules leads to modifications that indirectly open up the previously non-existent possibilities in the organisational market. This in turn causes a change in the structure of that market. Indeed, there is no legally justified reason for the governing bodies to insist on being a single undertaking in a market for the organisational services or on being the owner of the commercial rights in all of the sporting events under their regulatory competence. Conversely, vertical pyramid structure of regulatory authority has a good chance of survival under the EU competition law, provided that the principle proportionality is respected. Even though there is a good degree of fluidity in application of the economic provisions in sports industry which requires case-bycase approach, what makes a decisive difference in outcome of the cases is whether a specific regulatory rule protects public or private interests, and whether a 'specificity of sport' is involved. Those regulatory rules that serve private gains and do not benefit from the notion of 'specificity of sport' will eliminate the possibility of passing Meca-Medina test. As a matter of law, such rules may nevertheless benefit from similar commercial ancillarity analysis, Article 101(3) exemption and/or the equivalent economic efficiency defence under Article 102 TFEU. Sporting federations that maintain clauses in their rulebooks designed to block competing organisers will be forced to make necessary amendments and comply with the newly clarified legal environment, when and if challenged. The possibilities of entry into organisational market for potential competitors, as well as a possibility of expansion for the existing ones, must exist. This is bound to bring about a re-characterising of the business in the sports industry as it becomes more attractive for potential investors and opens more commercial opportunities for the actors within the sports industry.

\footnotetext{
${ }^{112}$ Higher Regional Court of Dusseldorf (Oberlandesgericht Düsseldorf) Beschluss vom 2. April 2013 · Az. VI U (Kart) 9/13. Available at https://openjur.de/u/633726.html

113 The defendant charges an authorization fee of $€ 30.00$ for association members and $€ 100.00$ for nonassociation organizers as well as a so-called event tax. This amounted to a uniform $10 \%$ of the start-up funds received by 2011 and amounts to 2.00 to $10.00 €$ for each participant at an approved event, depending on the competition distance.
} 